GRASAS Y ACEITES 68 (1)

January-March 2017, e177

ISSN-L: 0017-3495

doi: http://dx.doi.org/10.3989/gya.0335161

\title{
Effect of refrigeration time on the lipid oxidation and fatty acid profiles of catfish (Arius maculatus) commercialized in Cameroon
}

\author{
N. Tenyang ${ }^{\mathrm{a}, \mathrm{b}, \mathbb{}}$, H.M. Womeni ${ }^{\mathrm{b}}$, B. Tiencheu $^{\mathrm{b}, \mathrm{c}}$, P. Villeneuve $^{\mathrm{d}}$ and M. Linder ${ }^{\mathrm{e}}$ \\ ${ }^{a}$ University of Maroua, Faculty of Science, Department of Biological Sciences, P.O. Box 814 Maroua, Cameroon \\ ${ }^{b}$ University of Dschang, Faculty of Science, Department of Biochemistry, P.O. Box 67 Dschang, Cameroon \\ ${ }^{c}$ University of Buea, Faculty of Science, Department of Biochemistry, P.O. Box 63 Buea, Cameroon \\ ${ }^{\mathrm{d}}$ Laboratoire d'Ingénierie des Biomolécules, ENSAIA-INPL, 2 avenue de la Forêt de \\ Haye, 54500, Vandoeuvre-les-Nancy cedex, France. \\ ${ }^{\mathrm{e}}$ Laboratoire de Lipotechnie, CIRAD, UMR IATE, TA 40/16, 73 rue JF Breton, \\ 34398 Montpellier cedex 5, France. \\ Corresponding author: tenoel2003@yahoo.fr
}

Submitted: 31March 2016; Accepted: 21 November 2016

SUMMARY: The effects of refrigeration at $4{ }^{\circ} \mathrm{C}$ during 9 days on the quality and stability of catfish oil were evaluated using a change in fatty acid composition by gas chromatography (GC), commonly used analytical indexes (acid and peroxide values), and analysis by Fourier transform infrared (FTIR) spectroscopy. The results revealed that lipid deterioration, hydrolysis and oxidation occurred throughout the cold storage $\left(4^{\circ} \mathrm{C}\right)$. Refrigeration induced the lipolysis of triglycerides by lipases and phospholipases. It also affected the fatty acids composition of the catfish. The progressive loss of unsaturation was monitored by the decrease in the absorbance band at $3012 \mathrm{~cm}^{-1}$ on FTIR spectra and the lowest value was observed in the catfish muscle at 9 days of refrigeration. Eicosapentaenoic C20:5 13 (EPA) and docosahexaenoic C22:6 13 (DHA) acids were the polyunsaturated fatty acids most affected during refrigeration. Refrigeration for less than 5 days was found to be the best conditions for the preservation of the catfish.

KEYWORDS: Catfish; FTIR Spectroscopy; Lipid oxidation; Polyunsaturated fatty acids; Refrigeration

RESUMEN: Efecto del tiempo de refrigeración en la oxidación de lípidos y perfil de ácidos grasos del pez gato (Arius maculatus) comercializado en el Camerún. El efecto de la refrigeración a $4{ }^{\circ} \mathrm{C}$ durante 9 días sobre la calidad y estabilidad del aceite de pez gato se evaluó mediante el cambio en la composición de ácidos grasos por cromatografía de gases (CG), los índices analíticos comúnmente utilizados (acidez y peróxidos) así como mediante análisis por espectroscopia de infrarrojo por transformada de Fourier (FTIR). Los resultados mostraron que el deterioro de los lípidos, la hidrólisis y la oxidación ocurrieron durante el almacenamiento en frío $\left(4^{\circ} \mathrm{C}\right)$. La refrigeración indujo a lipolisis de triglicéridos por lipasas y fosfolipasas. También se vio afectada la composición de ácidos grasos, la pérdida progresiva de insaturación se controló mediante la disminución de la banda de absorbancia a $301 \mathrm{~cm}^{-1}$ en los espectros FTIR y el valor más bajo se observó en el músculo a los 9 días de refrigeración. Los ácidos eicosapentaenoico C20:5 3 (EPA) y docosahexaenoico C22:6ஸ3 (DHA) fueron los ácidos grasos poliinsaturados más afectados durante la refrigeración. Se encontró que la refrigeración durante menos de 5 días era la mejor condición para la conservación del pez gato.

PALABRAS CLAVE: Ácidos grasos poliinsaturados; FTIR Spectroscopy; Oxidación de los lípidos; Pez gato; Refrigeración

ORCID ID: Tenyang N http://orcid.org/0000-0002-6957-8092, Womeni HM http://orcid.org/0000-0001-6893-2865, Tiencheu B http://orcid.org/0000-0001-8209-2954, Villeneuve P http://orcid.org/0000-0003-1685-1494, Linder M http://orcid.org/0000-0002-8658-6828

Citation/Cómo citar este artículo: Tenyang N, Womeni HM, Tiencheu B, Villeneuve P, Linder M. 2017. Effect of refrigeration time on the lipid oxidation and fatty acid profiles of catfish (Arius maculatus) commercialized in Cameroon. Grasas Aceites 68, e177. http://dx.doi.org/10.3989/gya.0335161.

Copyright: (C) 2017 CSIC. This is an open-access article distributed under the terms of the Creative Commons Attribution (CC-by) Spain 3.0 License. 


\section{INTRODUCTION}

Fish is a major source of animal protein and it also contains vitamins and minerals. Fish contains significant amounts of essential amino acids particularly lysine, whose content is low in cereals. Fish protein can therefore be used to complement the amino acid pattern and the overall protein quality of a varied diet (FAO, 2005). Lipids are important because they carry odors and flavors and contribute to the palatability of meats. There are also potential benefits especially from the highly polyunsaturated fatty acids in marine fish (Socol and Oetterer, 2003).

In recent years, fish lipids also assumed great nutritional significance owing to their protective role against the development of coronary heart diseases, hypertension, certain cardiac arrhythmias and sudden death and diabetes (Leaf and Weber, 1998). In addition, it appears that fish lipid, especially n-3 polyunsaturated fatty acids, plays a vital role in the development and function of the nervous system (brain), photoreception (vision), and the reproductive system (Guesnet and Alexandri, 2005).

The lipid components of the post-mortem fish muscle tissue of marine fish are prone to oxidation due to their fatty acids, which are more unsaturated. Lipid oxidation is one of the major factors that reduces the quality and acceptability of meat and fat products. The oxidation process involves the degradation of PUFA, vitamins and other tissue components and the generation of free radicals, which lead to the development of rancid odors and changes in color and texture in foodstuffs (Kanner, 1994). Lipid oxidation is thought to promote the oxidative damage of proteins through the prooxidant activity of primary (hydroperoxides) and secondary (aldehydes, ketones) lipid oxidation products ( $\mathrm{Li}$ and King, 1999). Protein oxidation mainly occurs via free radical reactions in which peroxyl radicals generated in the first stages of PUFA oxidation can attract hydrogen atoms from protein molecules, leading to the formation of protein radicals. The formation of non covalent complexes between lipid oxidation products and reactive amino acids residues, as well as the presence of some particular metals, such as copper and iron, can also lead to protein radical generation. A cross-linking reaction between proteins and primary or secondary products of lipid oxidation can affect amino acids and decrease protein functionality (e.g. solubility and hydrophobicity) as a result of protein denaturation ( $\mathrm{Li}$ andKing 1999). The oxidative reaction can be influenced by many factors such as the fatty acid composition, the concentration of pro-oxidants, endogenous ferrous iron, myoglobin, enzymes, $\mathrm{pH}$, temperature and oxygen consumption (Underland, 2001).

The evaluation of fish lipid oxidation is normally based on analytical indexes, peroxide value (PV) and thiobarbituric acid reactive substances (TBARS), which stand out as indicators of primary and secondary oxidation products, respectively (Yerlikaya and Gokoglu, 2010). Recently, the evaluation of volatile compounds has become an additional indicator of lipid oxidation in fish samples (Ross and Smith, 2006). With respect to instrumental methods, infrared spectroscopy has been demonstrated to be a useful tool to monitor oxidative changes in edible oils (Guillén et al., 2004), due to the high information content of infrared spectra and the possibility of assigning specific absorption bands to particular functional groups.

Many studies analyze the profile of fatty acids in raw fish; however, fish and meats are usually consumed after cold storage and/or after some type of cooking. Freezing is widely used because it can increase the shelf life of meat, which retains properties similar to those of fresh meat (Campanone et al., 2006). The conditions in which frozen meat or fish are stored and displayed can have significant effects on their quality. The duration of storage, change in temperature, air/sun light exposure, and packaging can affect the quality of meat or fish (Méndez-Bustabad, 1999). Although frozen foods are microbiologically stable, they are prone to deterioration during storage due to chemical reactions, since enzymatic activity slows down but does not cease (Jiménez and Carballo, 2000). The main deterioration of refrigerated meat and fish results from processes of lipid oxidation and protein degradation, with muscle tissues being especially susceptible. These processes can determine the end point of the display life of frozen products (Jiménez and Carballo, 2000). There is little information available in the literature on the effect of cold storage on the lipid oxidation and fatty acids profile of the catfish (Clarias lazera) in China, but none concerning the influence of cold storage on the lipid oxidation and fatty acid profile of Catfish (Arius maculatus) commercialized and consumed in Cameroon. This study was therefore conducted to evaluate the effect of refrigeration time on the lipid oxidation and fatty acid profile of catfish (Arius maculatus) commercialized in the Wouri river coast in Cameroon.

\section{MATERIALS AND METHODS}

\subsection{Fish samples}

The Catfish (Arius maculatus) chosen for this study are the most commonly consumed species in Cameroon. Eighteen samples of catfish were purchased from the main representative fish market in Douala. The mean weight of the fish was $150 \mathrm{~g}$. The fish sample originated from the marine coast in Cameroon. After being purchased, they were transferred to the Laboratory of Food Biochemistry in 
the Department of Biochemistry at the University of Dschang in boxes containing ice. Whole fish were immediately washed and stored in the refrigerator at $4{ }^{\circ} \mathrm{C}$ for 9 days. During refrigeration at $4{ }^{\circ} \mathrm{C}$, two samples of fish were taken as the composite sample at $0,3,6$ and 9 days for analyses. The fish samples were washed and filleted.

\subsection{Lipid extraction}

After the cold storage of catfish at $4{ }^{\circ} \mathrm{C}$, all samples were minced. Lipid was extracted according to the Bligh and Dyer method (1959). The sample $(25 \mathrm{~g})$ was homogenized with $200 \mathrm{ml}$ of a chloroform:methanol:distilled water mixture $(50: 100: 50)$ at the speed of $9500 \mathrm{rpm}$ for $2 \mathrm{~min}$ at $4{ }^{\circ} \mathrm{C}$ using an IKA Labortechnik homogenizer (Selangor, Malaysia). The homogenate was treated with $50 \mathrm{ml}$ of chloroform and homogenized at 9500 rpm for $1 \mathrm{~min}$. Then, $25 \mathrm{ml}$ of distilled water were added and it was homogenized again for $30 \mathrm{~s}$. The homogenate was centrifuged at $3000 \mathrm{rpm}$ at $4{ }^{\circ} \mathrm{C}$ for 15 min using a RC-5B plus centrifuge (Sorvall, Norwalk, CT, USA), and transferred to a separating flask. The chloroform phase was drained off into a $125 \mathrm{~mL}$ Erlenmeyer flask containing about 2-5 g of anhydrous sodium sulphate, shaken very well, and decanted into a round-bottom flask through a Whatman No. 4 filter paper. The solvent was evaporated at $25^{\circ} \mathrm{C}$, using an EYELE rotary evaporator N-100 (Tokyo, Japan), and the residual solvent was removed by flushing with nitrogen. The extracted oils were then used for analysis.

\subsection{Measurement of free fatty acids (FFA)}

Free fatty acid content was determined according to the method of AFNOR (1981). The lipid sample $(0.1 \mathrm{~g})$ was dissolved in $100 \mathrm{~mL}$ of ethanol and 2 drops of phenolphthalein were added as an indicator and swirled vigorously. The mixture was then titrated with potassium hydroxide $(0.1 \mathrm{~N})$. The free fatty acid content (FFA) was expressed as $\%$ oleic acid.

\subsection{Measurement of Peroxide value (PV)}

Peroxide value was determined according to the method of Low and $\mathrm{Ng}$ (1978). The lipid sample $(1.0 \mathrm{~g})$ was treated with $25 \mathrm{~mL}$ of an organic solvent mixture (chloroform: acetic mixture, 2:3). The mixture was shaken vigorously, followed by the addition of $1 \mathrm{~mL}$ of a saturated potassium iodide solution. The mixture was kept in the dark for 5 min and 75 $\mathrm{ml}$ of distilled water were added and the mixture was shaken. $0.5 \mathrm{~mL}$ of starch solution $(1 \%, \mathrm{w} / \mathrm{v})$ was added to the mixture as an indicator. The peroxide value was determined by titrating the iodine liberated from potassium iodide with a standardized
$0.01 \mathrm{~N}$ sodium thiosulfate solution. The PV was expressed as mili-equivalents of free iodine per $\mathrm{kg}$ of lipid.

\subsection{Fatty acid profile}

Lipids were extracted from the muscle tissue using the Bligh and Dyer (1959) method, and the fatty acid composition of the oil was investigated after conversion of their Fatty Acid Methyl esters (FAME) using the boron trifluoride-methanol method (AOAC, 2000). The prepared methyl ester was injected into the gas chromatography (Shimadzu, Kyoto, Japan) equipped with a flame ionization detector (FID) at a split ratio of 1:20. A fused silica capillary column $(30 \mathrm{~m} \times 0.25 \mathrm{~mm})$, coated with a bonded polyglycol liquid phase was used. The analytical conditions were: injection port temperature of $250{ }^{\circ} \mathrm{C}$ and detector temperature of $270{ }^{\circ} \mathrm{C}$. The oven was programmed from 170 to $225^{\circ} \mathrm{C}$ at a rate of $1{ }^{\circ} \mathrm{C} / \mathrm{min}$ (no initial or final hold). Retention times of FAME standards were used to identify the chromatographic peaks of the samples. Fatty acid content was calculated based on the peak area ratio and expressed as $\mathrm{g}$ fatty acid/100 $\mathrm{g}$ oil.

\subsection{Fourier Transform infrared (FTIR) spectra analysis}

An FTIR analysis of the samples of Catfish oil was performed with a horizontal ATR trough plate crystal cell $\left(45^{\circ} \mathrm{ZnSe} ; 80 \mathrm{~mm}\right.$ long, $10 \mathrm{~mm}$ wide and $4 \mathrm{~mm}$ thick) (PIKE Technology, Inc., Madison, WI) equipped with a Bruker odel Vector 33 FTIR spectrometer (Brucker Co., Ettlingen, Germany). Prior to analysis, the crystal cell was cleaned with acetone, wiped dry with a soft tissue and the background scan was run. For spectra analysis, the oil sample $(200 \mu \mathrm{L})$ was applied directly onto the crystal cell and the cell was clamped into the mount of the FTIR spectrometer. The spectra, in the range of $4000-400 \mathrm{~cm}^{-1}$ (mid-IR region) with automatic signal gain, were collected in 16 scans at a resolution of $4 \mathrm{~cm}^{-1}$ and were compared against a background spectrum recorded from the clean, empty cell at $25^{\circ} \mathrm{C}$. An analysis of the spectral data was carried out using the OPUS 3.0 data collection software programme (Bruker, Wissembourg, France).

\subsection{Statistical analysis}

Data were obtained in triplicates and analyzed with the aid of Microsoft Excell 2010 software for Windows. The results were calculated and expressed as Mean \pm standard Deviation. All results were submitted to analysis of variance (ANOVA) at $0.05 \%$ probability level. The Bonferroni test was used to compare the means using the software graph Pad Instat, 2000. 


\section{RESULTS AND DISCUSSION}

\subsection{Changes in the acid value of oils extracted from refrigerated catfish}

Free fatty acid content is taken as a susceptibility to rancidity in order to assess the quality of oils. The percentage of oleic acid of the oils extracted from catfish muscle according to the duration of cold storage $\left(4^{\circ} \mathrm{C}\right)$ is depicted in Figure 1 . These results show that no changes in acid value were observed in the first 3 days of refrigeration $(\mathrm{P}<0.05)$. Subsequently, the acid value significantly increases after the first 3 days of refrigeration and the highest acid value was obtained on day $9(\sim 6.17 \%$ oleic acids). Our results are in agreement with those of Manat et al. (2006) who observed an increase in free fatty acid content in sardine (Sardinella gibbosa) muscle during iced storage. Lipid hydrolysis taking place during cold storage is an important change that occurs in fish muscle lipids post-morten with accumulation of free fatty acids. The increase in free fatty acid in catfish muscle could be attributable to hydrolytic enzyme activity such as endogenous lipases (Jimenez and Carballo, 2000). Some extracellular lipases produced by certain microorganisms such as pseudomonas fungi could also contribute to the production of free fatty acids (Pacheco-Aguilar et al., 2000).

\subsection{Changes in the peroxide value of oils extracted from refrigerated catfish}

Lipid oxidation is a rather complex process, whereby unsaturated fatty acids react with molecular oxygen via free radical chain mechanism and form fatty acyl hydroperoxides as primary products in the oxidation process ( $\mathrm{Li}$ and King, 1999).
Peroxide value is the most commonly used assay of oxidation in fats and oils. It measures rancidity or degree of oxidation but not the stability of the fat. The peroxide values of the oils extracted from catfish after refrigeration are presented in Figure 2. These results show that refrigeration significantly affected $(\mathrm{P}<0.005)$ the peroxide index of catfish lipids. During refrigeration, a significant decrease was found in the peroxide content and the sample stored for 9 days had the lowest peroxide value $(\sim 31.31 \mathrm{meq} / \mathrm{kg})$. A decrease in peroxide value confirms that during refrigeration, the components formed were unstable and were highly susceptible to further changes. They were rapidly transformed into various volatiles and non volatile compounds such as aldehydes, ketons, and acid (Nawar, 1996). Our current results are consistent with the research on surimi, obtained during the production of sea food products by Peng et al. (2016), which suggested that cold storage duration increases the production of secondary products of lipid oxidation, but remained in disagreement with those of Pacheco-Aguilar et al. (2000) who observed an increase in peroxide value in oily Monterey sardine stored at $0{ }^{\circ} \mathrm{C}$ for 15 days. The variation may be due to the storage temperature, the concentration of pro-oxidants, enzymes, ionic strength and oxygen consumption (MéndezBustabad, 1999).

\subsection{Changes in fatty acid profile}

Fat content and fatty acid composition of fish and meat are of major importance for consumers due to their importance for fish and meat quality and nutritional value (Wood et al., 2004). The consumption of fatty fish at least three times a week in the amount of 200-300 g according to recommendation (Stone, 1996) can play a significant role in

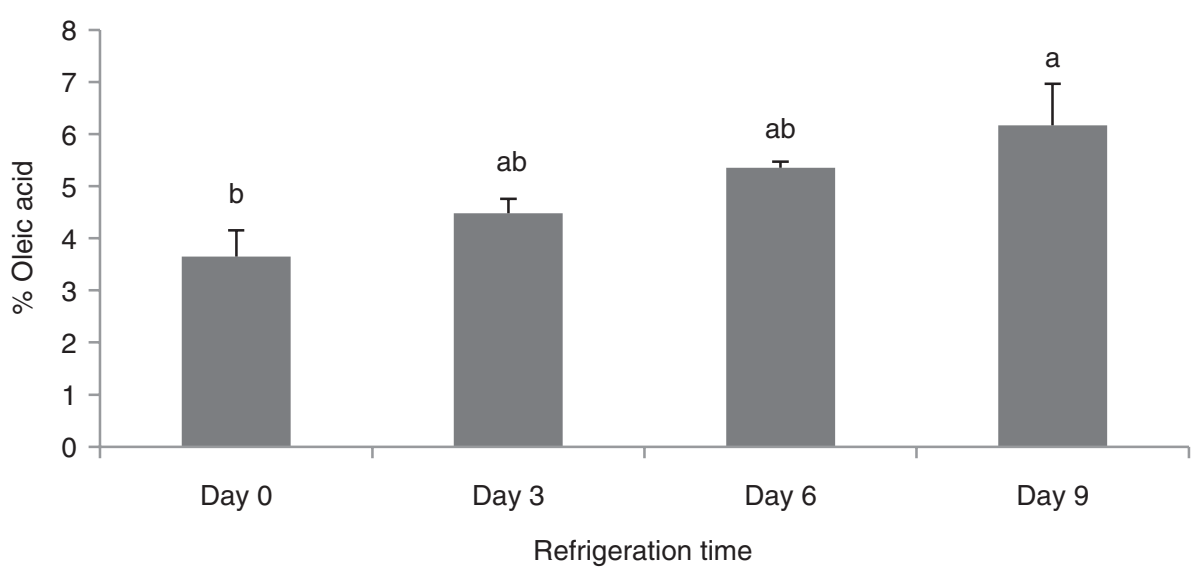

Results are means \pm standard error $(n=3)$. Bars that have no common letters are significantly different $(p<0.05)$

FIGURE 1. Changes in acid value of catfish muscle during refrigeration. 


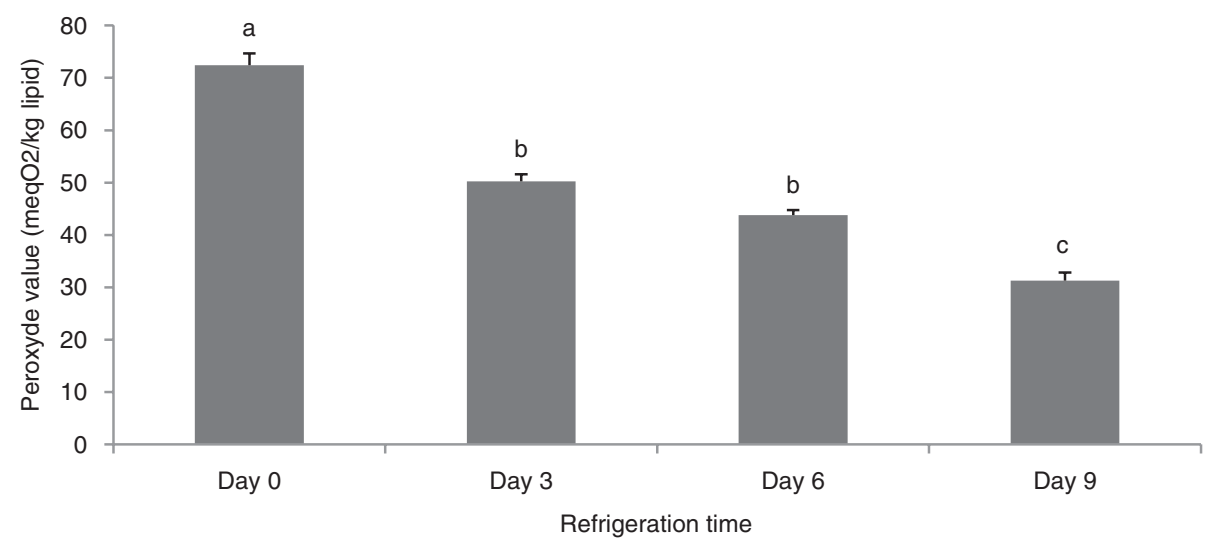

Results are means \pm standard error $(n=3)$. Bars that have no common letters are significantly different $(p<0.05)$

FIGURE 2. Changes in peroxide value of catfish muscle during refrigeration.

preventing cardiovascular diseases. The profile of the most important fatty acids of catfish stored at $4{ }^{\circ} \mathrm{C}$ (refrigeration) during 9 days is presented in table 1 . The most abundant fatty acids found in raw catfish were oleic acid (C18:1n-9) palmitic acid (C16:0) and stearic acid (C18:0). These findings are in agreement with those reported by other authors for catfish samples (Weber et al., 2008, Peng et al., 2016). Raw catfish also showed considerable amounts of myristic acid (C14:0), palmitoleic acid (C16:1), eicosapentenoic acid (C20:5n-3: EPA) and docosahexanoic acid (C22:6n-3: DHA). DHA is the dominant n-3 fatty acid in marine fish. Since DHA is the major component of brain, eye retina and heart muscle, DHA has been considered as important for brain and eye development and also good for cardiovascular health (Leaf and Weber, 1998). However, catfish had low levels of the n-3 PUFA linolenic acid (C18:3n-3). The n-3/n-6 ratio (1.73) of raw catfish in this study is high when compared to that of Japanese catfish $(\sim 1)$, and to that obtained by Weber et al. (2008) on catfish $(0.3)$.

During refrigeration, changes in saturated, monounsaturated and polyunsaturated fatty acids were observed in this fish throughout the storage period. The SFA content decreased with refrigeration time. The MUFA content increased with refrigeration time and the highest value was obtained after 6 days of storage $(\mathrm{P}<0.05)$. Decreases in PUFA, especially arachidonic acid (C20:4n-6), eicosanoic acid (EPA) and docosahexaenoic acid (DHA; C22:6n3) were also observed, particularly as the storage time increased. EPA decreased by $39 \%$ and $48 \%$ at day 6 and day 9 , respectively. For DHA, it decreased by $42 \%$ and $45 \%$ at day 6 and day 9, respectively. The PUFA content had little or no variation for the first 3 days of refrigeration, but decreased significantly at day 6 of refrigeration and the lowest value was obtained after 9 days of refrigeration. The marked decrease in PUFA might be due to its susceptibility to oxidation. Free PUFA may undergo oxidation to a greater extent than SFA. This result was evidenced by a decrease in PUFA during refrigeration time. However, arachidonic acid (C20:4n6) and docosahexaenoic (DHA, C22:6n3) are potential substrates of oxidation enzymes (Josephson and Lindsay, 1986). Our results are in agreement with those obtained by Chaijan et al., (2006) who observed a decrease in PUFA during ice storage. Roldan et al. (2005) detected a certain effect of storage after freezing in hake (Merluccius merluccius) fillets consisting of a decline in the $\mathrm{n}-3$ fatty acid content, this being more evident in pre-spawned fish. Harris and Tall (1994) reported that fish contains high levels of highly unsaturated fatty acids and they are susceptible to oxidative rancidity. The observations obtained in this work are not in agreement with those mentioned by Pirini et al. (2000) who found no significant differences in the fatty acid profile of muscle lipids of fish and therefore in nutritional quality over the entire storage period.

\subsection{Analytical evaluation of the change occurring in catfish oils during cold storage by infrared spectroscopy (FTIR)}

Crude lipids extracted from raw catfish were also characterized by FTIR (Figure 3). Generally, the FTIR spectrum exhibited similar regions of functional group vibrations as reported previously for mackerel fish lipids (Giménez et al. 2011), farmed salmon fillet lipids (Guillén and Cabo 2004), as well as for some vegetable oils (Vlachos et al., 2006).

On the spectrum of Figure 3, we can identify the different functional groups of the oils at 
TABLE 1. Changes in fatty acid profile of catfish muscle during refrigeration

\begin{tabular}{|c|c|c|c|c|}
\hline \multirow[b]{2}{*}{ Fatty acids (g/100g oil) } & \multicolumn{4}{|c|}{ Storage time (days) } \\
\hline & $\mathbf{0}$ & 3 & 6 & 9 \\
\hline $\mathrm{C} 12: 0$ & $0.71 \pm 0.00^{c}$ & $0.76 \pm 0.00^{c}$ & $1.02 \pm 0.01^{b}$ & $1.58 \pm 0.08^{\mathrm{a}}$ \\
\hline C14:0 & $3.44 \pm 0.43^{\mathrm{b}}$ & $3.24 \pm 0.08^{b}$ & $3.16 \pm 0.13^{b}$ & $4.12 \pm 0.01^{\mathrm{a}}$ \\
\hline $\mathrm{C} 16: 0$ & $21.90 \pm 0.01^{\mathrm{a}}$ & $20.67 \pm 0.09^{\mathrm{b}}$ & $18.88 \pm 0.01^{\mathrm{c}}$ & $18.47 \pm 0.11^{d}$ \\
\hline C16:1 & $5.81 \pm 0.01^{\mathrm{a}}$ & $6.37 \pm 0.24^{\mathrm{a}}$ & $5.79 \pm 0.00^{\mathrm{a}}$ & $6.31 \pm 0.25^{\mathrm{a}}$ \\
\hline $\mathrm{C} 17: 0$ & $2.40 \pm 0.13^{b}$ & $2.61 \pm 0.01^{b}$ & $3.73 \pm 0.03^{\mathrm{a}}$ & $3.42 \pm 0.08^{\mathrm{a}}$ \\
\hline $\mathrm{C} 17: 1$ & $1.86 \pm 0.07^{\mathrm{a}}$ & $1.82 \pm 0.10^{\mathrm{a}}$ & $1.39 \pm 0.06^{\mathrm{b}}$ & $1.36 \pm 0.08^{b}$ \\
\hline C18:0 & $12.80 \pm 0.01^{\mathrm{bc}}$ & $12.08 \pm 0.26^{\mathrm{c}}$ & $13.53 \pm 0.32^{b}$ & $14.89 \pm 0.18^{\mathrm{a}}$ \\
\hline C18:1n-9 & $14.96 \pm 0.73^{\mathrm{c}}$ & $14.90 \pm 0.15^{\mathrm{c}}$ & $19.76 \pm 0.06^{b}$ & $23.21 \pm 0.43^{\mathrm{a}}$ \\
\hline C18:2n-6 & $3.49 \pm 0.09^{\mathrm{a}}$ & $2.75 \pm 0.04^{\mathrm{a}}$ & $2.27 \pm 0.20^{\mathrm{b}}$ & $1.80 \pm 0.00^{\mathrm{b}}$ \\
\hline C18:3n-6 & $0.71 \pm 0.00^{\mathrm{b}}$ & $0.97 \pm 0.05^{\mathrm{a}}$ & $0.92 \pm 0.01^{\mathrm{a}}$ & $0.90 \pm 0.02^{\mathrm{a}}$ \\
\hline C18:3n-3 & $0.54 \pm 0.01^{\mathrm{b}}$ & $0.76 \pm 0.01^{\mathrm{ab}}$ & $0.83 \pm 0.09^{\mathrm{a}}$ & $0.90 \pm 0.02^{\mathrm{a}}$ \\
\hline C20:0 & $4.57 \pm 0.08^{c}$ & $5.14 \pm 0.02^{\mathrm{b}}$ & $5.25 \pm 0.01^{b}$ & $5.62 \pm 0.03^{\mathrm{a}}$ \\
\hline C20:1n-9 & $1.05 \pm 0.00^{\mathrm{c}}$ & $0.95 \pm 0.05^{\mathrm{c}}$ & $4.14 \pm 0.25^{\mathrm{b}}$ & $5.20 \pm 0.04^{\mathrm{a}}$ \\
\hline$C 20: 4 n-6$ & $3.15 \pm 0.14^{\mathrm{a}}$ & $3.25 \pm 0.02^{\mathrm{a}}$ & $3.01 \pm 0.02^{\mathrm{a}}$ & $2.04 \pm 0.06^{\mathrm{a}}$ \\
\hline C20:5n-3 (EPA) & $6.55 \pm 0.36^{\mathrm{a}}$ & $4.36 \pm 0.06^{b}$ & $3.96 \pm 0.02^{c}$ & $3.37 \pm 0.14^{c}$ \\
\hline $\mathrm{C} 22: 0$ & $0.83 \pm 0.18^{\mathrm{a}}$ & $0.85 \pm 0.20^{\mathrm{a}}$ & $0.96 \pm 0.03^{\mathrm{a}}$ & $1.20 \pm 0.04^{\mathrm{a}}$ \\
\hline C22:1 & $0.46 \pm 0.01^{\mathrm{a}}$ & $0.48 \pm 0.01^{\mathrm{a}}$ & $0.39 \pm 0.08^{\mathrm{a}}$ & $0.47 \pm 0.05^{\mathrm{a}}$ \\
\hline$C 22: 4 n-6$ & $1.94 \pm 0.03^{\mathrm{a}}$ & $1.87 \pm 0.08^{\mathrm{ab}}$ & $1.99 \pm 0.03^{\mathrm{a}}$ & $1.68 \pm 0.03^{\mathrm{b}}$ \\
\hline$C 22: 5 n-3$ & $3.12 \pm 0.11^{\mathrm{a}}$ & $3.00 \pm 0.13^{\mathrm{ab}}$ & $2,76 \pm 0.06^{\mathrm{ab}}$ & $2.50 \pm 0.15^{\mathrm{b}}$ \\
\hline C22:6n-3 (DHA) & $5.91 \pm 0.12^{\mathrm{a}}$ & $4.92 \pm 0.03^{\mathrm{b}}$ & $3.40 \pm 0.06^{\mathrm{c}}$ & $3.23 \pm 0.05^{\mathrm{c}}$ \\
\hline Saturated fatty acid (SFA) & $46.65 \pm 0.84^{\mathrm{b}}$ & $45.35 \pm 0.66^{\mathrm{b}}$ & $46.53 \pm 0.54^{\mathrm{b}}$ & $49.30 \pm 0.62^{\mathrm{a}}$ \\
\hline Monounsaturated fatty acid (MUFA) & $24.14 \pm 0.85^{\mathrm{c}}$ & $24.52 \pm 0.55^{\mathrm{c}}$ & $30.47 \pm 0.45^{\mathrm{b}}$ & $34.55 \pm 0.85^{\mathrm{a}}$ \\
\hline Polyunsaturated fatty acid (PUFA) & $25.41 \pm 0.85^{\mathrm{a}}$ & $23.38 \pm 0.42^{\mathrm{a}}$ & $19.14 \pm 0.49^{\mathrm{b}}$ & $16.42 \pm 0.47^{\mathrm{c}}$ \\
\hline$n-3 / n-6$ & 1.73 & 1.50 & 1.33 & 1.56 \\
\hline$\Sigma \mathrm{NI}$ & 3.8 & 6.75 & 2.86 & - \\
\hline
\end{tabular}

$\mathrm{NI}=$ Unidentified; Values are means \pm standard deviation $(\mathrm{n}=3)$. From triplicate determination, different letters in the same line indicate significant differences $(\mathrm{P}<0.05)$.

room temperature between 3800 and $800 \mathrm{~cm}^{-1}$. The band associated with the overtone of the glyceride ester carbonyl absorption showed a maximum absorbance near $3448 \mathrm{~cm}^{-1}$ (Guillén et al., 2004). The weak band associated with hydroxyl groups newly formed during oxidation appears in the figure near $3350 \mathrm{~cm}^{-1}$. Lazzari and Chiantore in 1999 found similar bands when analyzing the oxidative degradation of linseed lipids. The peak at $3010 \mathrm{~cm}^{-1}$, related to the $\mathrm{C}-\mathrm{H}$ stretching vibration of the cis-double bond $(=\mathrm{CH})$, appeared at the same wave number in salmon lipids (Guillén et al., 2004). The two peaks just below 3000 (2924 and $2853 \mathrm{~cm}^{-1}$ ) can both be assigned to absorption caused by asymmetric and symmetric stretching vibrations of methyl groups, and the peak at $1750 \mathrm{~cm}^{-1}$ is related to absorption caused by stretching vibrations of ester groups. Setiowaty et al. (2000) reported a value of $1746 \mathrm{~cm}^{-1}$. Smith (1998) reported that changes in IR band positions were typically caused by changes in the electronic structure, as well as changes in the force constant of a molecule. The bands associated with the fingerprint region observed between $1500 \mathrm{~cm}^{-1}$ and $900 \mathrm{~cm}^{-1}$ can accurately characterize the molecules similar to those bands reported for lipids from different sources. However, it should be noted that the peaks at $1375 \mathrm{~cm}^{-1}$ and $1461 \mathrm{~cm}^{-1}$ are associated with deformation vibrations of $\mathrm{CH}_{2}$ and $\mathrm{CH}_{3}$ groups. These bands were also found by Guillén and Cabo (1999). According to Guillén and Cabo (1997), the peaks at $1250 \mathrm{~cm}^{-1}$ and $1150 \mathrm{~cm}^{-1}$ would be associated with the stretching vibration of the $\mathrm{C}-\mathrm{O}$ ester group and the bending vibration of the $\mathrm{CH}_{2}$ group, both related to the proportion of saturated acyl groups in the oil sample. 


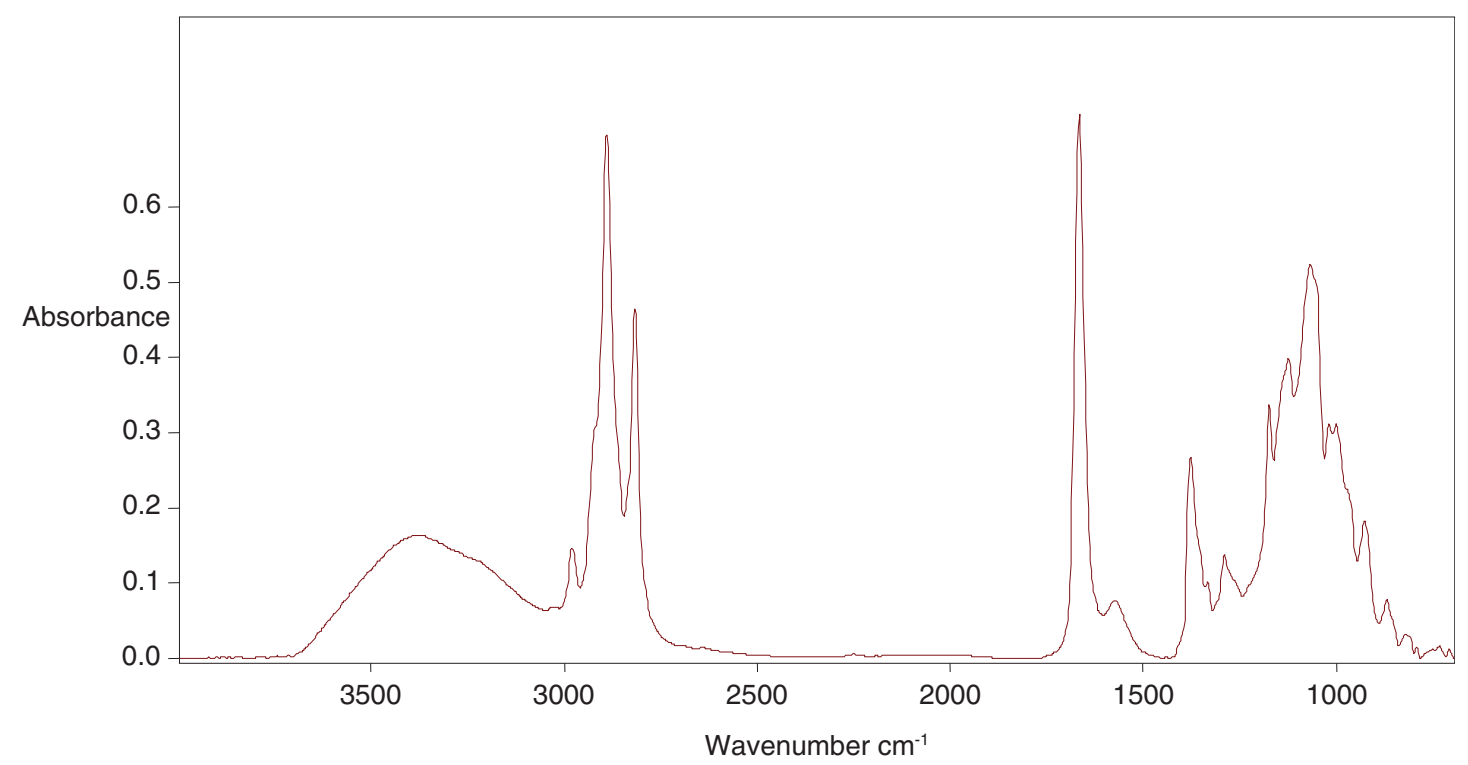

FIGURE 3. Representative Fourier transform infrared spectrum of lipids extracted from raw catfish in $3800-800 \mathrm{~cm}^{-1}$ region.

Figure 4 shows the effect of refrigeration on select IR regions taken from the spectra of the lipids extracted from catfish. The dominant spectral features in the region from 3800 to $3100 \mathrm{~cm}^{-1}$ (Figure 4A) were linked to hydroxyl groups newly formed during the oxidation (Chaijan et al., 2006; Gruillén et al, 2004). A Noticeably decreased absorbance in the region between $3800-3100 \mathrm{~cm}^{-1}$ during refrigeration was observed. The absorbance of this band became less intense at day 9 of refrigeration. Decreases in the absorbance band at $3800-3100 \mathrm{~cm}^{-1}$ suggest the decomposition of hydroperoxide to yield secondary products of lipid oxidation (Chaijan et al, 2006). This result coincides with the decrease in PV obtained by the titrimetric method during refrigeration. A reduction in the degree of lipid unsaturation of catfish lipid due to an eventual oxidative process during refrigerated duration could be evidenced by monitoring the peak at $3012 \mathrm{~cm}^{-1}$ (Figure 4B). At this wave number, the unrefrigerated sample has the highest absorbance and therefore constitutes the greatest unsaturated oil, while the refrigerated sample had a weak absorbance at day 9 . Lipid oxidation is one of the most important factors responsible for the deterioration of fish during storage. A decrease in the band at $3012 \mathrm{~cm}^{-1}$ during refrigeration is due to lipid oxidation. Chaijan et al. (2006) also reported a reduction in unsaturated fatty acids during the iced storage of sardine (Sardinella gibbosa) due to lipid oxidation. At $2950 \mathrm{~cm}^{-1}, 2850 \mathrm{~cm}^{-1}$ (Figure 4B), $1460 \mathrm{~cm}^{-1}$ and $1370 \mathrm{~cm}^{-1}$ (Figure 4D), the results obtained call for similar conclusions. The peaks obtained characterize the stretching vibrations of $\mathrm{CH}_{2}$ functional groups. However, it is observed that the intensities of the peaks decreased and the stored sample had the weakest band at day 9 while the highest band was attributed to the unrefrigerated sample. The decrease in these peaks is related to the oxidation of lipids with a decrease in double bonds. The results obtained at $3012 \mathrm{~cm}^{-1}$ were in correlation with those obtained at 2950 , 2850, 1460 and $1370 \mathrm{~cm}^{-1}$ wave numbers. The IR absorbance at $1750 \mathrm{~cm}^{-1}$ (Figure $4 \mathrm{C}$ ), attributed to the esters of the triglycerides exclusively, was not considerably reduced during refrigeration. The absorbance of the peaks at $1160 \mathrm{~cm}^{-1}$ (Figure 4D) showed a clear tendency to decrease at day 9 of refrigeration. The decrease in the intensity of this band during processing is related to lipid oxidation. These results are similar to those obtained by Manat et al. (2006) in the study of the changes of lipids in sardine (Sardinella gibbosa) during ice storage. The absorbance of the peak at $1147 \mathrm{~cm}^{-1}$ showed a clear tendency to decrease at day 9. These peaks are related to the proportion of saturated acyl groups. Specifically, the latter, associated with the stretching vibration of the C-O group in esters, was reported to be inversely related to the proportion of saturated acyl groups in oil samples (Guillen and Cabo, 1997). The observed lowering in the concentration of $\mathrm{C}-\mathrm{O}$, $\mathrm{CH} 2$ as well as $\mathrm{CH} 3$ functional groups could be related to the production of dimmers and polymers of triglycerides during lipid oxidation. Muik et al. (2007) reported that increasing bands between $980-950 \mathrm{~cm}^{-1}$ are related to the vibration 
a)

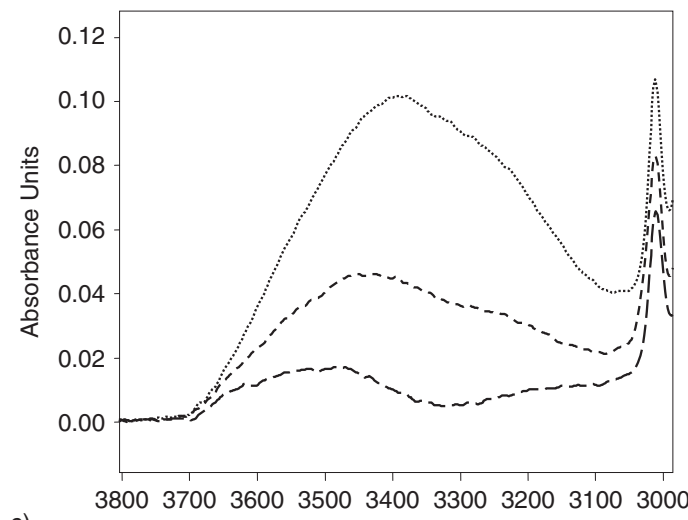

c)

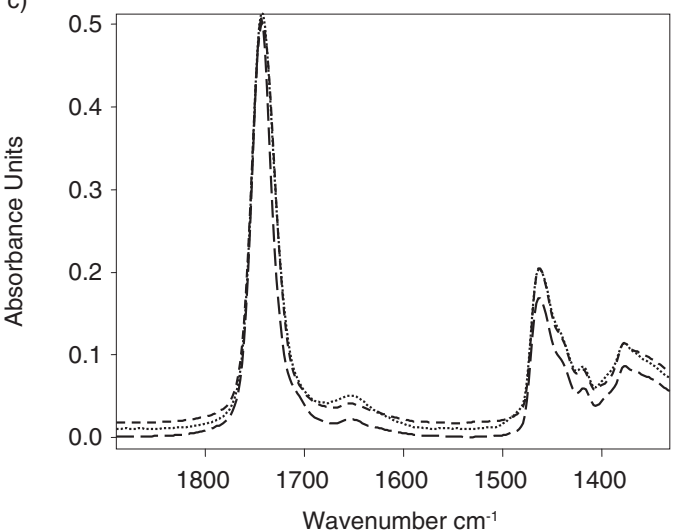

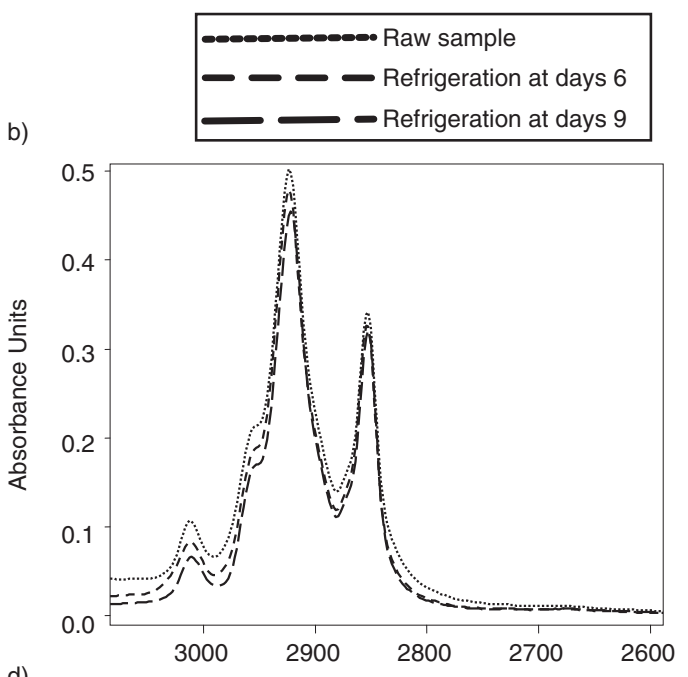

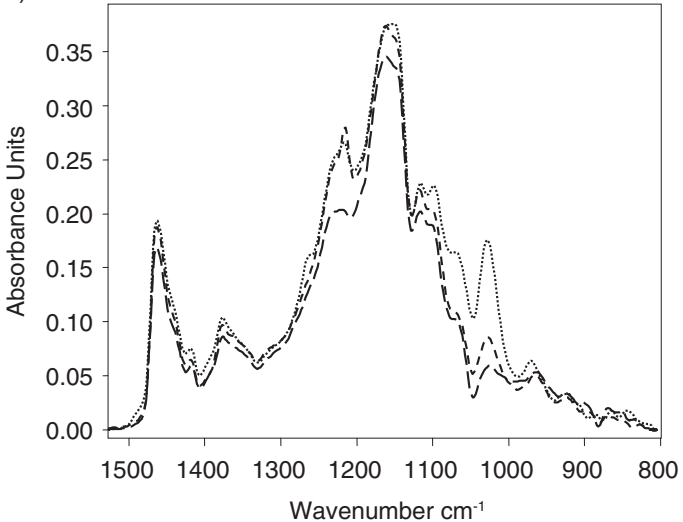

FIGURE 4. Selected region (A)-(D) of FTIR spectra of lipids extracted from refrigerated catfish.

in the molecules analyzed of trans double bonds. In the case of this study, no difference seemed to exist between the samples.

\section{CONCLUSIONS}

The effects of refrigeration time on catfish lipids were examined. The data obtained in this study showed that refrigeration has greater impact on the storage stability of catfish oil. Free fatty acid formation and decrease in triglycerides during storage indicate an increased lipolysis. When catfish lipid is stored at low temperatures $\left(4^{\circ} \mathrm{C}\right)$, the initial nature of the triglyceride changes significantly and the decrease in unsaturation is evidence of the transformation occurring in the polyunsaturated fatty acids such as EPA and DHA which the lipid initially contains, thus indicating a decrease in the quality of catfish lipid. Refrigeration at $4{ }^{\circ} \mathrm{C}$ for less than 5 days was found to be the best method for catfish lipid preservation.

\section{REFERENCES}

AFNOR. 1981. Recueil des Normes Françaises. Corps Gras, Graines Oléagineuses, Produit Dérivés, $2^{\text {nd }}$ Édition, AFNOR, Paris, 1981.

AOAC. 2000. Official methods of analysis. Washington, DC: Association of Official Analytical Chemists.

Bligh EC, Dyer WJ. 1959. A rapid method of total lipid extraction and purification. Can. J. Biochem. Physiol. 37, 911-917. http://dx.doi.org/10.1139/o59-099

Campañone LA, Roche LA, Salvadori VO, Mascheroni RH. 2006. Structural studies on unpackaged foods during their freezing and storage. J. Food Sci. 71, 218-226.

Chaijan M, Benjakul S, Visessaguan W, Faustman C. 2006. Changes of lipids in sardine (Sardinella gibbosa) muscle during iced storage. Food Chem. 99, 81-83. http://dx.doi. org/10.1016/j.foodchem.2005.07.022

FAO. 2005. United Nations Food \& Agriculture Organisation, Nutritional elements of Fish. FAO Rome.

GiménezB, Cómez-Guillén MC, Pérez-Mateos M, Montro P, Márquez-Ruiz G. 2011. Evaluation of lipid oxidation in horse mackerel patties covered with borage-containing film during frozen storage. Food Chem. 124, 1393-1403. http:// dx.doi.org/10.1016/j.foodchem.2010.07.097

Guesnet P, Alexandri JM. 2005. Acides gras polyinsaturés du lait et développement du système nerveux central du nouveau né. Cah. Nutr. Diet 30, 109-116. 
Guillén MD, Cabo N. 1999. Usefulness of the frequency data for the Fourier transfor infrared spectra to evaluate the degree of oxidation of edible oils. J. Agric. Food Chem. 47, 709-719. http://dx.doi.org/10.1021/jf9808123

Guillén MD, Cabo N. 1997. Infrared spectroscopy in the study of edible oils and fats. J. Sci. Food Agric. 75, 1-11. http://dx.doi. org/10.1002/(SICI) 1097-0010(199709)75:1<1::AIDJSFA842>3.0.CO;2-R

Guillén MD, Ruiz A, Cabo N. 2004 Study of the oxidative degradation of farmed salmon lipids by jeans of Fourier transform infrared spectroscopy. Influence of salting. $J$. Sci. Food Agric. 84, 1528-1534. http://dx.doi.org/10.1002/ jsfa. 1811

Harris P, Tall J. 1994. Rancidity in Fish. In J.C. Allen \& R.J. Hamilton (Eds.), Rancidity in Foods, 257-272. London, UK: Chapman.

Jiménez F, Carballo J. 2000. Capítulo IV: Aplicaciones del frío a la carne y productos cárnicos (pp. 293-313). In Coordinado por M. Lamúa (Ed.), Aplicación del frío a los alimentos (p. 350). Madrid: AMV Ediciones y Mundi Prensa.

Josephon DB, Lindsay RC. 1986. Enzymic generation of volatile aroma compounds from fresh fish. In Biogeneration of Aromas. Parliment TH, Croteau R, eds. ACS symposium series No. 317, American Chemical Society, Washington, DC, USA, 201-219.

Kanner J. 1994. Oxidative processes in meat and meat products: quality implications. Meat Sci. 36, 169-186. http://dx.doi. org/10.1016/0309-1740(94)90040-X

Li LK, King AJ. 1999. Structural changes of rabbit myosin subfragment I altered by malondehyde, a byproduct of lipid oxidation. J. Agric. Food Chem. 47, 3124-3129. https://doi. org/10.1021/jf990028y

Lazzari M, Chiantore O. 1999. Drying and oxidative degradation of linseed oils: Polym. Degrad. Stab. 65, 303-313. http://dx.doi.org/10.1016/S0141-3910(99)00020-8

Leaf A, Weber PC. 1988. Cardiovascular effects of n-3 fatty acids. N. Engl. J. Med. 318, 549. http://dx.doi.org/10.1056/ NEJM198803033180905

Low LK, Ng. 1978. Determination of peroxide value. In $\mathrm{H}$. Hasegawa (Ed.), Laboratory manual on analytical methods and procedures for fish and fish products (pp.C7.1-C7.3). Singapore: Marine Fisheries Research Department, Southeast Asian Fisheries Development Center.

Manat C, Soottawat B, Wonnop V, Cameron F. 2006. Changes of lipids in sardine (Sardinelle gibbosa) muscle during ices storage. Food Chem. 99, 83-91. http://dx.doi.org/10.1016/j. foodchem.2005.07.022

Méndez-Bustabad O. 1999. Weight loss during freezing and the storage of frozen meat. J. Food Eng. 41, 1-11.

Muik B, Lendi B, Molina-Diaz A, Valcarcel M, Ayora-Canada MJ. 2007. Two dimentional correlation spectroscopy and multivariate curve resolution for the study of lipid oxidation in edible oils monitored by FTIR and Fr-Raman spectroscopy. Anal. Chim. Acta 593, 54-67. http://dx.doi. org/10.1016/j.aca.2007.04.050

Nawar WW. 1996. "Lipids", In: O.R. Fennema, Ed., Food Chemistry, Marcel Dekker, Inc., New York: 225-314.
Pacheco-Aguilar R, Lugo-Sanchez ME, Robles-Burgueno MR. 2000. Postmortem biochemical characteristic of Monterey sardine muscle stored at $0{ }^{\circ} \mathrm{C}$. J. Food Sci. 65, 40-47. http://dx.doi.org/10.1111/j.1365-2621.2000. tb15953.X

Peng L, Hua Y, Yingchun Z, Yang W, Dongqing B, Ruitong D, Xiaoqing R, Hongshun Y, Lizhen M. 2016. Influence of Washing and Cold Storage on Lipid and Protein Oxidation in Catfish (Clarias lazera) Surimi. J. Aquat. Food Prod. 25, 790-801. http://dx.doi.org/10.1080/10498 850.2014 .931898

Pirini M, Gatta PP, Testi S, Trigari G, Monetti PG. 2000. Effect of refrigerated storage on muscle lipid quality of sea bass (Dicentrarchus labrax) fed on diets containing different levels of vitamin E. Food Chem. 68, 289-293. http://dx.doi. org/10.1016/S0308-8146(99)00190-9

Roldan HA, Roura SI, Montecchia CL, Borla OP, Crupkin MC. 2005. Lipid changes in frozen stored fillets from pre- and postspawned hake (Merluccius hubbsi Marini). J. Food Biochem. 29, 187-204. http://dx.doi. org/10.1111/j.1745-4514.2005.00006.x

Ross CF, Smith DM. 2006. Use of volatiles as indicators of lipid oxidation in muscle foods. Comp. Rev. Food Sci. Food Safety 5,18-25.http://dx.doi.org/10.1111/j.1541-4337.2006. tb00077.x

Setiowaty G, Che Man YB, Jinap S, Moh MH, 2000. Quantitative determinations of peroxide value in thermally oxidized palm olein by Fourier transform infrared spectroscopy. Phytochem. Anal. 11, 74-78. http://dx.doi. org/10.1002/(SICI)1099-1565(200003/04)11:2<74::AIDPCA498>3.0.CO;2-E

Smith BC. 1998. The basics of infrared interpretation. In B.C. Smith (Ed.), Infrared spectral interpretation: A systematic approach (pp1-29). New York, USA: CRC Press, Inc.

Socol MCH, Oetterer M. 2003. Seafood as functional food. Braz. Arch. Biol. Techn. 46, 443-454.

Stone NJ. 1996. Fish consumption, Fish oils lipids and coronary heart disease. Circulation 94, 2337-2340. http://dx.doi. org/10.1161/01.CIR.94.9.2337

Underland I. 2001. Lipid oxidation in fatty fish during processing and storage. In SC Kestin \& P.D. Warris (Eds.). Farmed Fish Quality (Pp261-275). UK: Fishing News Books, Black Welle Science.

Vlachos N, Skopelitis Y, Psaroudaki M, Konstantinidou V, Chatzilazarou A, Tegou E. 2006. Applications of Fourier transform-infrared spectroscopy to edible oils. Anal. Chim. Acta 573, 459-465. http://dx.doi.org/10.1016/j. aca.2006.05.034

Weber J, Bochi VC, Ribeiro CP, Victorio AM, Emanuelli T. 2008. Effect of different cooking methods on oxidation, proximate and fatty acid composition of Silver Catfish (Rhamdia quelen) fillets. Food Chem. 106, 140-146. http://dx.doi. org/10.1016/j.foodchem.2007.05.052

Yerlikaya P, Gokoglu N. 2010. Inhibition effects of green tea and grape seed extracts on lipid oxidation in bonito fillets during frozen storage. Int. J. Food Sci. Technol. 45, 252-257. http://dx.doi.org/10.1111/j.1365-2621.2009.02128.x 